DOI https://doi.org/10.18551/rjoas.2017-11.47

\title{
THE EFFECT OF SOCIAL RESPONSIBILITY TOWARDS THE CORPORATE IMAGE OF TELKOM KANDATEL OF EAST SURABAYA, INDONESIA
}

\author{
Kurniawan Gogi \\ Management Study Program, STIE Yapan Surabaya, Indonesia \\ E-mail: info@stieyapan.ac.id
}

\begin{abstract}
This reseach measured Social Responibility as the independent variable and Company's Image as the dependent variable. The population of this study involved 104 members of environment development conducred by Community Development Center as a part of social responsibilty program of Telkom in East Surabaya. In this research, census technique was used to determine the sample of this study since 104 members were taken as the sample. The data obtained in this research were then analyzed using Structural Equation Modelling. Hypothesis testing, causal relationship and direct relationship (path coefficient) were measured from the standard regression value by comparing the critical ratio or similar probability to the t-value. The significance effect was shown by t-value that was higher than the t-table. Based on the result and the discussion of this study, it can be concluded that there was no significant effect from social responsibility toward company's image.
\end{abstract}

\section{KEY WORDS}

Social responsibility, company's image, social impact, corporate study.

Economic development in Indonesia has started to grow after great economic crisis which can be seen from the massive development of economic sectors. However, the development triggers competition among institutions. Today's regulation forces companies to show their transparency, allowing anyone to find out any information related to the companies including companies' social responsibility programs, regardless of time and places.

The tight competition often lured companies from their function as social organizations in addition to their function as business institutions. Some challenges appear related to the business since companies are required to maintain good interaction with the surrounding social environment in order to perform their operational activities.

Companies that have high motivation to improve their corporate social responsibility role should grow awareness on the current social issues. Corporate social responsibility also functions as protection for the companies in case some unexpected problems occur.

Social duties are important to create good image of the companies, which also give strong contribution to the sustainable development of the companies. Hence, it is obvious that social contribution affects the image of a company. The company image itself is regarded valuable.

It is important that companies show good social attitude to maintain their images. Companies should not only focus on earning profit, but they also have to give positive contribution to the surrounding environment and society. Companies that activate their social responsibility show that they care about the society and the environment.

Problems related to CSR of companies in Indonesia should not be merely investigated from the pros and cons debate as stated by Friedman (1970) and Roddick (2004). On the other hand, social problems such as high number of poverty and illiteracy, difficult access to health services, low quality of education sector, natural disasters, poor system of public transportation are waiting to be solved by the government.

Unfortunately, the requirement for companies to activate their corporate social responsibility rises a contra-productive debate. The regulation gives an impression that the government hand over the responsibility to the companies. On the other side, companies 
object to regarding CSR as a duty. As the result, companies tend to see CSR as a new entity that is expected to give positive contributions to solve social problems in Indonesia.

Nation's social responsiblity can be illustrated as a big meal, while CSR is the vitamin. The needs of the Indonesians are under governments' responsibility which should not be handed over to other parties. The main necessities of the society should be fulfilled by the government at the first place.

According to the World Bank, corporate social responsibility contains several fundamental components; environmental protection, safety insurance, human rights, interaction between the companies and the society, standard operational procedure, economic development, business orientation, health care, leadership, education, and disaster aids.

The theories and the principles of CSR might seem complete and promising, its feasibility is still debatable. CSR should not only be charged to industrial companies that have some negative impacts to the environment and the society, but CSR should also be charged to other companies such as financial companies, bank and non-bank. Unfortunately, some companies are known to perform various violations such as damaging the environment, violating the human rights, termination of employment, and keep receiving loans form strong companies in the world.

Based on those facts, TELKOM has made an attempt to put CSR as a part of its business strategies. The management of CSR in TELKOM is officially written in a decision made by the directors.

Through a unit called Telkom Community Development Center (Telkom CDC) which was established in 2007, PT. Telkom run a program called Program Kemitraan dan Bina Lingkungan (PKBL) as a realization of the CSR. Telkom had been managing an affiliate program since 2007 - 2012 which has involved 30.908 affiliates, and has spent 356.54 billion rupiah to provide loans for the sociey. Meanwhile, Telkom also had been running an environmental progrm since 2009-2013 in which it has spent 51.56 billion rupiah for the charity program. The environmental program included aids for education and training in the forms of scholarship, laboratory improvement, facilitation of school tools (computer, books, etc), internships, teacher development program and the Internet Goes to School program.

The affiliate programs run by State-Owned Companies (BUMN) with micro enterprises are aimed at improving the capability of the micro businesses to grow stronger and independent using the fund from the companies. Micro business refers to small-scale business run by the society which fulfills certain criteria including the criteria related to the yearly sales and ownership set by the companies. Micro-scale enterprises that fulfilled the criteria were chosen to receive loans from the companies.

The lack of information provided in the official website of Telkom (www.pkbltelkom.com) and the lack of exhibitions were probably the factors that make the society have few information related to the procedure to apply for the loans as affiliate partners of Telkom CDC East Surabaya.

The low interest shown by the society to affiliate with Telkom CDC East Surabaya was also triggered by the uncertainty about the exact time to receive the loan. Thus, the society tends to apply for loans from banks or cooperatives which have clearer procedures. .

Table 1 shows the decrease in the number of affiliates of CDC East Surabaya.

Tabel 1 - The Segmentation of Affiliates in CDC East Surabaya

\begin{tabular}{|c|c|c|c|c|c|c|c|}
\hline \multirow{2}{*}{ Year/Segmentation } & \multicolumn{7}{|c|}{ Segmentation } \\
\cline { 2 - 8 } & Industry & Service & Trading & Fishery & Agriculture & Husbandry & Sum \\
\hline 2007 & 1 & 5 & 6 & & & & 12 \\
\hline 2008 & 46 & 49 & 67 & & & 4 & 166 \\
\hline 2009 & 40 & 33 & 61 & 5 & & 16 & 155 \\
\hline 2010 & 35 & 43 & 32 & 2 & & 28 & 140 \\
\hline 2011 & 100 & 260 & 236 & 9 & 5 & 45 & 655 \\
\hline 2012 & 77 & 131 & 130 & 2 & 2 & 26 & 368 \\
\hline 2013 & 37 & 24 & 41 & 1 & & 1 & 104 \\
\hline
\end{tabular}

Source: CDC East Surabaya. 
Some enterprises had successfully fulfilled the criteria to receive the loan in CDC East Surabaya, yet some problems occurred including:

1. The evaluation process took too much time and there was no certain schedule for the affiliates to receive the fund.

2. When surveys toward affiliates' enterprises were done outside Surabaya, the service of Telkom CDC East Surabaya was disturbed since there were only 3 officers-in charges for taking care of the affiliates all around the area of Telkom CDC East Surabaya including Mojokerto, Jombang, Trawas, Sidoarjo and East Surabaya.

In additon, affiliates often paid their installment late, which forced the officers to conduct home visit.

Corporate social responsibility can be used as a business strategy to improve the competitiveness of the company by creating good images and building customers' loyalty. Those aspects can become a great strength for a company to win the business competition. On the other hand, the tendency of the customers to buy goods based on certain criteria, values and ethics is expected to modify the customers' behavior in the future. The development of CSR is a continuum process that should be developed continuously. Thus, a good ecosystem that gives benefit for the customers in the forms of good quality and ecofriendly products, and the companies also receive high profit, which profit is then indirectly distributed back to the society (Daniri, 2007: 1).

A theory on the companies imaging taps on the importance of the goal determination as proposed by Gene Broadwater (Stephen P. Robbins, 2001: 177) in which he stated that the main target of a companies is to build better performance and good image. Generally, companies with good images have these six characteristics: good relationship with society leaders, positive relationship with local government, lower business risks, pride of being a part of an organization and the society, mutual understanding among members of the organization and the ssociety, and high loyalty of the employees (Anggoro, 2002: 21).

\section{THEORETICAL FRAMEWORK}

The Definition of Marketing. Marketing is one of the main activities performed by businessman in running a business to earn higher profit. Marketing holds a crucial role in reaching the target of a company. Kotler (1997: 8) mentioned that marketing is a social and managerial processes in which (either individuals or groups) members get their necessities and their expectations fulfilled by producing, offering and exchanging valuable products with other parties.

Based on the definition above, one should firstly determine their necessities before they start some attempts to fulfill them by maintaining good relationship with other individuals. Marketing activity is started from the identification of what the customers want and need, determination of the products to fulfill customers' needs, determination of the proper price of the product, determination of the promotion method and media, and determination of the effective distribution procedure to reach the goals. Hence, marketing should not be regarded as an easy activity that only aims at earning money.

A set of interrelated marketing attempts are done to reach the exchange target as expected in the target market which is generally called marketing management.

Social Responsibility. Social responsibility is a basic theory on the importance of a company to maintain harmonious relationship with the surrounding environment. Theoretically, social responsibility is defined as a moral contribution of a company to its stakeholders including communities and the society around it. Social responsibility makes a company become a moral agent. Regardless of the presence of any law on the matter, a good company should always care about the morality. The parameter of a company's success seen from its ability in managing the social responsibility is how far the company regard moral and ethical principles within their attempts to obtain the best result without any negative impacts to the society. One of the famous moral principles is the golden rules which teach how to treat other person the way we want to be treated. Therefore, companies that highly regard moral and ethical principles are able to give strong contribution to the society. 
In fact, Corporate Social Responsibility (CSR) is often neglected by some companies. Unfortunately, companies that fulfill their CSR obligation are often given negative labels by other companies. There were also some companies that successfully give real contribution to the society, yet the companies failed at obtaining society's sympathy. Some companies also failed in their attempts to do some charity work in order to build up good images at the same time. Those failures occurred because companies tend to simply set the CSR into immature programs without adequate planning (Badri, 2007). The practice of CSR is not as easy as its concepts for it requires deep understanding and comprehension on the integrated social aspects considering the fact that any decision related to CSR might affect the society. Companies are motivated to seek for a balance point between implementing an effective CSR program and earning profit.

CSR emphasizes logic and objective consideration of social welfare and it also function as a control upon human behavior as well as to prevent companies from causing damages. Therefore, the implementation of CSR should not focus on the return, yet it should put more concern on how strong it gives positive contribution to the social welfare.

The implementation of CSR is more challenging than it may look. This is due to the requirement of deep and fundamental comprehension on the its contribution toward any social aspect since the change on the concept also affect the society. Companies should find a threshold point between a good concept of CSR and the return (Steiner and Miner, 1998: $54)$.

The Indicator of Corporate Social Responsiblity. Siltaoja (2006: 98) highlights the strong relationship between CSR and sustainable development which suggests that a company should not only focus on the financial aspects in making certain decision, but it should also concern on the contribution to the social and environmental aspects in the future. In order to put it into a good practice, a company is suggested to use these indicators proposed by Anggraini, 2007: 5 which are: a.Transparency, b.Knowledge, c.Sustainability.

Companies' Image. Soemirat and Ardianto (2004: 14) state that company image refers to how other parties see a company. The number of a company's image goes equally with the number of the society, customers, potential consumers, bankers, staffs, competitors, distributors, suppliers, affiliates, and retailer who might have diverse views about the company. Generally, companies obtain good images have these six characteristics: good relationship with society leaders, positive relationship with the government, lower risks of crisis, pride of being the part of the society, mutual understanding between the company and the society, and loyalty of the staffs (Anggoro, 2002: 44).

Jefkins (2003:45) mentioned some types of image as follows:

a. Mirror Image

Refers to the image attached to members of an organization especially leaders and how the society seees the organization.

b. Current Image

Refers to how others create certain images of an organization.

c. Wish Image

Refers to the images expected by a corporate management.

d. Corporate Image

Refers to the whole and hollistic image of an organization, not only the images about the product and service offered by a company.

e. Multiple Image

High number of employees and their heterogeneity create different images which do not always go in line with the corporate image.

Corporate Image Indicators. Corporate images deals with how other parties view the company which is mostly affected by these following factors (Anggraini, 2007: 6): a. the quality of product and service, b. the orientation to the customers, c. environmental responsibility, d. the implementation of good corporate governance.

The Effect of Corporate Social Responsibility toward Corporate Image. Good management of CSR in a company creates strong trust which enhances employees' motivation and commitment. Consumers, investors, suppliers, stakeholders and other parties 
also tend to give more positive support to companies that they consider maintaining good social responsibility. As the result, companies that implement good CSR management tend to show better performance and earn hinger profit which later also improves the corporate image.

The basic theory of social responsibility is the theory of group creation proposed by Homans (2003: 80) which emphasizes on the activities, interaction, and sentiments among a society. The more frequent interaction is made with other individual, the more diverse the type of interaction and the stronger the sentiment among a society. More interaction leads to more sentiment, and more sentiment leads to modifications on the activities and the intearction itself. A theory on the grouping was proposed along with the theory of social balance by Newcomb which were consutructed based on the similar behavior shown in facing certain relevant goals among each others (Homans, 2003: 80). Any action related to CSR affects the corporate image. In addition, the theory of institution suggests that a company run a good management of CSR in order to maintain its sustainability. Good management of CSR is believed to drive good intention and legitimation to the extern constitution which is a key determinant to the betterment of corporate image and its sustainability (Handoko, 1992: 262).

\section{METHODS OF RESEARCH}

Variables and operational definitions in this study include:

Social Responsibility (X) which refers to a commitment made by a company in maintaining harmonious relationship with the society shown by these indicators:

1. Transparency refers to the how a company provide accessible information about its progress in implementing the social responsibility.

2. Knowledge refers to the adequate insights built by a company related to the proper subjects to receive CSR aids.

3. Sustainability refers to the commitment of a company in implementing a sustainable CSR program.

Corporate Image $(Y)$, which refers to how others view a company which can be measured from these indicators:

- The quality of product and service offered by a company from the quality aspect up to the hospitality.

- The priority given to the customers upon other condiderations.

- Social responsibility as a real action of corporate's concern on social matters.

- The practice of good corporate governance

The population of this study involved 104 members of Program Kemitraan dan Program Bina Lingkungan under the management of a unit called the Community Development Center (CDC) which was appointed to manage the social responsibility duties of PT. Telkom in East Surabaya. Survey technique was employed to determine the samples of this study since this study involved all of the population as the samples.

\section{RESULTS AND DISCUSSION}

One-Step Approach Test. In the context of SEM model, measurement model and the the structural model of each parameter is administered at one. Thus, to fulfill the requirement of the fit model is a challenging task. The possibility of interaction between the measurment model and the structural model should be estimated at once using the One Step Approach to SEM. The One Step Approach to SEM technique is generally used when the model has been supported by adequte theory and it has high validity and reliability (Hair, et.al., 1998).

The result of the estimation and the fit model using the one step approach to SEM technique using application program Amos 4.01 are presented in the following Goodness of Fit Figures and Tables.

The result of the one step base model evaluation shows that each goodness of fit criteria has reached good values, which implies that the model has been suitable with the 
data. In another word, the conceptual model that was constructed based on the theories used in this study is supported by the facts obtained in this study. Reliability test result indicates an internal consistency in which some indicators were eliminated that results a modification on the model as follows.

Company Social Responsibility, \& Company Image

Model Specification: One Step Approach - Base Model

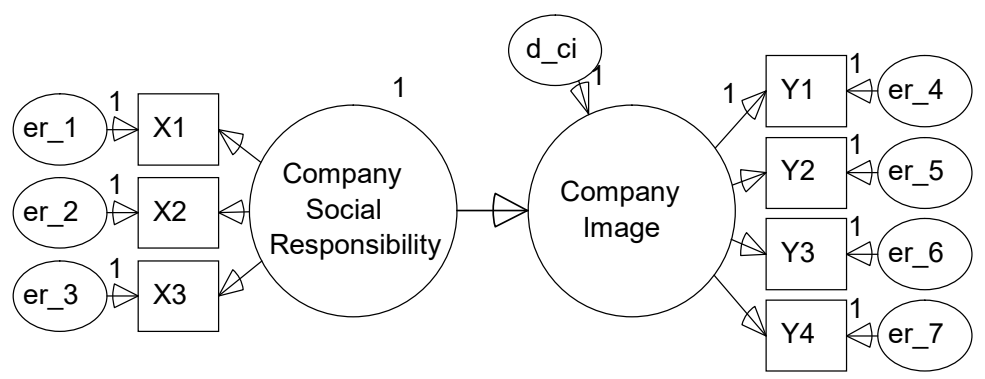

Figure 1 - The Measurement of Causality Model using One Step Approach

Table 2 - The Criteria of Goodness of Fit Indices

\begin{tabular}{|c|c|c|c|}
\hline Criteria & Result & Critical Value & Evaluation \\
\hline Cmin/DF & 0.837 & $\leq 2.00$ & Low \\
\hline Probability & 0.620 & $\geq 0.05$ & Low \\
\hline RMSEA & 0.000 & $\leq 0.08$ & Low \\
\hline GFI & 0.970 & $\geq 0.90$ & Low \\
\hline AGFI & 0.935 & $\geq 0.90$ & Low \\
\hline TLI & 1.010 & $\geq 0.95$ & Low \\
\hline CFI & 1.000 & $\geq 0.94$ & \\
\hline
\end{tabular}

Source: Data Analysis.

Company Social Responsibility, \& Company Image

Model Specification: One Step Approach - Base Model

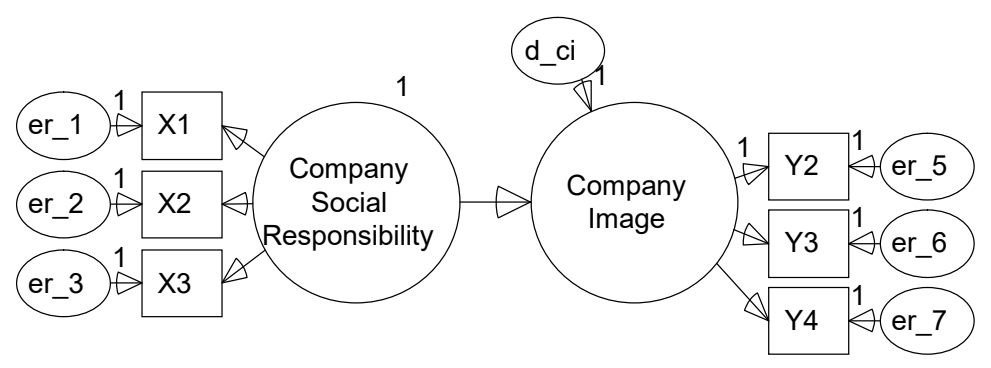

Figure 2 - Measurement and structural model

Table 3 - Evaluation Criteria of Goodness of Fit Indices

\begin{tabular}{|c|c|c|c|}
\hline Criteria & Result & Critical Value & Evaluation \\
\hline Cmin/DF & 0.671 & $\leq 2.00$ & Good \\
\hline Probability & 0.718 & $\geq 0.05$ & Good \\
\hline RMSEA & 0.000 & $\leq 0.08$ & Good \\
\hline GFI & 0.983 & $\geq 0.90$ & Good \\
\hline AGFI & 0.955 & $\geq 0.90$ & Good \\
\hline TLI & 1.014 & $\geq 0.95$ & Good \\
\hline CFI & 1.000 & $\geq 0.94$ & \\
\hline
\end{tabular}

Source: Data analysis.

The result of the evaluation on the one step elimination model shows that each criteria of the goodness of fit used in this study obtained good result which means the data have been suitable with the model. It means that the design of the conceptual model based on the 
related theories has been supported by the facts obtained in this study. Therefore, it can be drawn into a conclusion that the developed model appears as the best model to explain the intercorrelation among some variables in the model as follows.

Regarding the determinant of sample covariance matrix value at $4.022 .779 .399>0$, it does not indicate any presence of multicolinierity or singularity in the data which implies that the assumption of the study has been fulfilled. Hence, the coefficient regression of each factor is valid, proven by the result of the causality test as follows.

The Hypothesis and Causal Relationship Tests. Direct influence (path coefficient) can be observed from the score of the standardized regression through critical ratio test (CR) or $p$ (probability) equal to the $t$ value. The value is regarded significant if $t$ value is greater that the $t_{\text {table. }}$

Table 4 - Result of the Causality Test

\begin{tabular}{|l|l|c|c|c|}
\hline & Factors & Ustd Estimate & Std Estimate & Prob. \\
\hline Company Image & Company Social Responsibility & 0.1 & 0.154 & 0.197 \\
\hline \multicolumn{2}{|c|}{ Significance limit } & $\leq 0.10$ \\
\hline
\end{tabular}

Source: Data analysis.

Seen from the probability of the causal relationship orientation, the hypothesis which stated that the factor of the company social responsibility has a positive influence on the factor company image cannot be accepted [causal probability at $0.197>0.10$ [insignificant [positive].

\section{DISCUSSION OF RESULTS}

The results of this study show that the social responsiblity does not significantly affect corporate image. The result of the data analysis indicates that social responsbility has no significant influence on corporate image. Thus, it can be implied that the company has not yet applied an effective and efficient CSR management due to the limited number of staffs and lack of information received by the society which caused the program did not optimally run. This problem has resulted inadequate impact given by the company to the society. Moreover, the society shared a believe that good CSR pratice means higher job opportunities offered by a company to the society in a certain area in order to improve the welfare of the people living around it. In fact, the true substance of the CSR is the sustainability of the company itself which can be maintained from the enhancement of team work among stakeholders and the facilities given by a company for the social deveopment.

At the present time, CSR has not yet appeared as a general dea. Yet, in the era of advance information and technology, as well as the rapid growth of globalization, the requirement to run the CSR is greater. In addition, there has been a prediction that in 2009, ISO 260000 on CSR will be issued which will emphasize on the importance of the corporate social responsibility for the sustainability of the companies and to create good corporate image.

The result of this study goes contradictory to the theory on social grouping proposed by Homans based on the activities, interactions, and sentiments of the society. This theory states that more activities done by an individual that involve other individual leads to more diverse interactions and stronger sentiments. More interaction also triggers moresentiment which makes the probability of imitation of certain activities and interaction stronger. The theory on socia grouping was constructed from an idea proposed by Newcomb based on the similarity of behavior in achieving certain relevant goal among a society (Homans, $2003: 80$ ). Similarly, social responsibility held by a company significantly affects its corporate image. Furthermore, the institutional theory urges that a company should create a good management of CSR in order to run its extern constitution. This action is believed to have strong trigger in driving good intentions and legitimation of the extern constitution, which later ensures the sustainability of a company and uplifts its corporate images (Handoko, 1992: 262). 


\section{CONCLUSION AND SUGGESTIONS}

Based on the result of this study, it can be concluded that there is no significant influence of corporate social responsibility on the corporate image. This result implies that the implementation of the corporate social responsibility performed by the company has not yet effective and precise due to the lack of accessible information and the limited number of staffs to take care of this matter. Consequently, the management of CSR could not run optimally, and the company was regarded having low contribution to the society since the society measures the contribution of a company from company's ability to provide broader job opportunity and how the company is able to improve the society welfare.

Based on the findings of this study, companies are recommended to precisely measure the fund needed to run their social responsibility duties for the society. This problem should be taken into account considering the fact that CSR gave a negative effect to the development of a company. Companies, especially PT. Telkom East Surabaya should improve the corporate image since the image reflects internal trust in the company, emotional and intellectual relationship among employees, the target related to the consumers and stakeholders, besides it also shows the credibility of the company.

\section{REFERENCES}

1. Ferdinand, Augusty, 2002, Structural Equation Modeling Dalam Penelitian Manajemen, Penerbit BP Undip, Semarang.

2. Fitri Ismiyanti, 2006, "Corporate Citra melalui pendekatan corporate Social responsibility di lingkungan PT.PERKEBUNAN NUSANTARA X"

3. Hair, J.F. et. Al, 1998, Multivariate Data Analysis, Fifth Edition, Prentice-Hall International, Inc., New Jersey.

4. Hartline, Michael D. and O.C. Ferrell, 1996, "The Management of Customer-Contact Service Employees : An Empirical Investigation”, Journal of Marketing.

5. Kotler, Philip, 1997, Manajemen Pemasaran : Analisis, Perencanaan, Implementasi, Dan Kontrol, Penerbit Prenhallindo, Jakarta.

6. 2000, Marketing Management: Analysis, Planing, Implementation and control, The Millenium Edition, Prectice Hall International, Inc. New Jersey.

7. Peggy Simcic Brønn, 2006, "Tanggung Jawab Sosial Korporat Dan Pemasaran Yang Berhubungan Dengan Penyebab: Sebuah Tinjauan".

8. Robbins, Stephen P. 2001, Organization Behavior: Concepts, Controversies Aplication, Sevent Edition, Pretice Hall, Inc., New Jersey.

9. Tabachnick B.G., 1996, Using Multivariate Statistics, Third Edition, Harper Collins College Publisher. 